\title{
A Review of Undergraduate Evolution Education in U.S. Universities: Building a Unifying Framework
}

\author{
Jenny D. Lloyd-Strovas • Ximena E. Bernal
}

Published online: 18 August 2012

(C) Springer Science+Business Media, LLC 2012

\begin{abstract}
Despite a considerable amount of scientific evidence, evolution is still a highly controversial issue in American education. This review analyzes studies that investigate the relationship between evolution education, the nature of science, and religious beliefs in U.S. universities. We performed a comprehensive literature search focusing on publications that analyzed and compared at least two of the following constructs: understanding of evolutionary theory (ET), acceptance of ET, instruction in ET, prior exposure to ET, religious beliefs, understanding the nature of science, and understanding of scientific theories. Here, we examine publications for consistent relationships among constructs across studies and discuss the most commonly cited education strategies for teaching evolution in higher education. Based on the literature, we find that instruction has a significant and positive effect on acceptance and understanding of ET; acceptance and understanding, however, are not directly related. We also find that the relationship between acceptance of ET and religious beliefs is unclear and needs further research. Through reviewing 15 published studies, we find that the primary problems associated with undergraduate evolution education research are: small sample size, varying methodologies, lack of statistical analysis, inappropriate use of constructs, and lack of continuity among studies. This review exposes the need for a unifying framework and development of experts in this field to investigate and understand the factors that affect evolution education at U.S. universities.
\end{abstract}

\footnotetext{
J. D. Lloyd-Strovas $(\bowtie) \cdot$ X. E. Bernal

Biological Sciences, Texas Tech University,

Box\# 43131, Lubbock, TX, USA

e-mail: jenny.strovas@ttu.edu

X. E. Bernal

Smithsonian Tropical Research Institute,

Apartado 0843-03092, Balboa, Ancón,

Panama, Republic of Panama
}

Keywords Acceptance · Understanding · Instruction · Religious belief $\cdot$ Nature of science $\cdot$ Scientific theories

\section{Introduction}

Evolution is a central and unifying theme in biology that provides a foundational framework for explaining a broad range of intriguing biological questions (National Academy of Sciences 1999; Rutledge and Mitchell 2002; Scharmann 1993). Why is there an immense diversity of organisms on our planet? Why do most organisms have two sexes? Why do seemingly superfluous creatures like mayflies even exist? Why do some organisms live for a day and others live for a hundred years? These questions can be sufficiently answered only through the theory of evolution (Dobzhansky 1973). Simply stated, this theory describes how populations change over time due to changes in allele frequencies (Freeman and Herron 2007). The theory of evolution describes genetic change in form, function, and behavior of organisms across generations due to natural selection, chance (e.g., genetic drift), historical contingencies (e.g., distributional patterns), and changing environments (National Center for Science Education 2012).

Despite conclusive scientific evidence supporting evolutionary change, a large percentage of U.S. citizens do not accept evolution as a scientific theory. The percentage of U.S. citizens accepting the theory of evolution, for instance, was only $40 \%$ based on a national survey of U.S. citizens' views toward evolution that was implemented in 2005 (Miller et al. 2006). U.S. citizens also seem to have become increasingly neutral on this issue since acceptance of evolution dropped from $45 \%$ to $40 \%$ while the percentage of adults rejecting this theory declined from $48 \%$ to $39 \%$ between 1985 and 2005. Likewise, the percentage of U.S. citizens who reported not being sure about the validity of 
evolution increased from $7 \%$ to $21 \%$ during this time. These results suggest that U.S. citizens are equally divided among those who accept and reject evolution with about one in five persons either remaining undecided or unaware of the issue (Miller et al. 2006). Although a large percentage of U.S. citizens reject or ignore the theory of evolution, among scientists there is little argument on the validity of this well-established and supported theory (American Association for the Advancement of Science 1989; National Academy of Sciences 1999; National Research Council 1985; Alters and Alters 2001; Alters and Nelson 2002).

This apparent gap in the layman's acceptance of evolutionary theory (ET) has been attribute to an inadequate: (1) understanding of the nature of science, (2) understanding of scientific theories, (3) congruence with religious beliefs (Trani 2004, pp. 1-3); and (4) evolution education (Wilson 2005; Berkman et al. 2008). Here, we offer a critical review of the literature on the teaching of evolution in relation to the religious beliefs of students, addressing the components described above, with the exception of evolution's congruence with religious beliefs. The philosophical differences between science and religion have been extensively discussed (e.g., Laudan 1988; Smith 2001; Roy 2005; Ratzch 2009) and extend beyond the issues discussed here. We thus focus on the understanding of science, scientific theories and evolution education, and how these components relate to the challenge of teaching evolution at the undergraduate level. Below, we describe these components and provide the framework to evaluate them.

\section{The Nature of Science}

In order for people to accept evolution as a wellsupported scientific theory, they must first understand the nature of science itself. Science involves two primary elements: the practice of conducting science and the knowledge that results from this practice (Reiss 2009). In practicing science, scientists investigate phenomena and their resulting explanations through empirical and/or theoretical evidence. The resulting knowledge should be testable, falsifiable, repeatable, and unbiased (Flammer 2006; Smith 1994).

The testability of science makes it inherently different and therefore incompatible with the nature of religion. One may have faith in a higher being; one cannot objectively and empirically test, however, for the existence of a higher being. This does not mean that a higher being does not exist; it simply means that the scientific process cannot be used as a tool to examine religious faith (Flammer 2006). Because science is testable, it also lends itself to being falsifiable. This indicates that science is tentative and subject to change in light of new evidence; therefore, scientists should be open-minded and prepared to alter their knowledge (Reiss 2009; Smith 1994; Cherif et al. 2001). Science must also be repeatable, indicating that experimental results are verifiable by others. Repeatability is the foundation for developing scientific theories (Smith 1994). Lastly, science should be unbiased; in other words, it should not be subject to the opinions of scientists, politics, or society (Flammer 2006; Cherif et al. 2001; Smith 1994; Reiss 2009). A lack of understanding of the nature of science will inevitably lead to an ill-formed view of evolution. Without understanding science, it is impossible to understand scientific theories.

\section{Scientific Theories vs. Colloquial Theories}

Scientific theories are vastly different from the layman's colloquial use of the word theory. To the layman, a theory is simply a guess or hypothesis that tries to explain an observed phenomenon (Trani 2004); a scientific theory, however, is an explanation of a natural phenomenon based on a large amount of scientific evidence. In addition to being explanatory, scientific theories also have the ability to predict future events. This predictive power is the result of an explanation based on a unity of well-established knowledge (Smith 1994). In other words, scientific theories are able to explain and predict natural phenomena because they are based on a multitude of scientific studies. A scientist accepts a theory based on empirical evidence that adequately validates the overall concept-his/her views are not to be tainted by opinions, personal religious convictions, or beliefs (Smith 1994). Scientific theories, however, are based on scientific evidence, and science is subject to change; therefore, scientific theories can be modified, or even falsified, if there is enough evidence to support a change in paradigm (Reiss 2009; Smith 1994; Cherif et al. 2001). The theory of evolution is a well-established scientific theory and has been validated by a vast number of studies in varying academic areas such as biology, geology, paleontology, etc.

Even though evolution is an established scientific theory, people often struggle to understand and accept it while other scientific theories, like gravity, are rarely questioned. Although not surprising, this dichotomy reflects an important difference between the components necessary for understanding and acceptance of ET compared with other scientific theories. The theory of gravity is confirmed on a daily basis through first-hand experience. In contrast, the theory of evolution is more elusive, and its understanding requires attention to empirical evidence and inference processes. In addition, ET conflicts with the worldview of many people. Understanding how science works is thus essential for students learning about theories such as evolution that may be perceived as being in direct conflict with their belief system (Scharmann 1990, 1993; Sinclair et al. 1997; Nelson 2000; Alters and Nelson 2002; Sinatra et al. 2003). 
Consistently, Nelson (2000) suggests that many students view publically controversial theories as weaker than scientific theories that are not controversial. This may be due to a lack of integrative knowledge between scientific disciplines and the inability to discern the strengths of scientific ideas (Nelson 2000). Ultimately, this reiterates the necessity to establish a strong understanding of the nature of science. The relevance of having such solid foundation is supported by Shtulman and Valcarcel's (2012) work on students' tendency to retain naive (colloquial) theories even after they have learned the science behind the theory. By having a better understanding of the nature of science at a young age, for instance, students may be able to more readily accept publicly controversial scientific theories and find reconciliation between such theories and their worldview. The critical value of understanding the nature of science can and should be addressed in public education.

\section{Evolution Education}

The open controversy of evolution education in public schools began in 1925 when John Scopes, a biology teacher in Tennessee, gave his students a reading assignment concerning Darwinian evolution. At that time, the Butler Act prohibited the teaching of evolution in Tennessee schools. Scopes' reading assignment was in direct violation of the law; therefore, he was taken to trial, convicted, and fined \$100. Although this battle for evolution education was lost, it prompted the war to include evolution in public education. The Butler Act was finally dismissed in 1968 when it was declared unconstitutional by the U.S. Supreme Court on the basis of separation of church and state (Freeman and Herron 2007). Today, science learning objectives for primary and secondary education are at the mercy of state education agencies, subject to a level of educational bias based on state politics and religious groups. State agencies, however, are monitored by the state academies of science and the National Center for Science Education which allows for some emphasis to be placed on ET, even though learning objectives may vary in detail and quality for each state (Berkman et al. 2008).

The low percentage of U.S. citizens that accept evolution as a valid scientific theory (Miller et al. 2006) suggests that U.S. education systems are not adequately representing and teaching this well-established theory to students. This assumption has been tested by multiple studies conducted on K-12 teachers' and students' acceptance and understanding of evolution (e.g., Sinclair and Baldwin 1995; Lawson and Wornsop 1992; Zimmerman 1987; Rutledge and Mitchell 2002; Trani 2004); fewer studies, however, have been conducted at the university level. U.S. undergraduates are an important population because they are being trained to be our nation's future policy makers, business owners, educators, etc. According to the
U.S. Census Bureau (2004), approximately half of all U.S. citizens have had some type of college education and about $27 \%$ obtain a degree. Higher education is intended to develop students into independent, analytical thinkers. If a quarter of our population is college educated, and these people are independent thinkers, then why are U.S. citizens becoming more neutral in their views of evolution, a well-established scientific theory?

This study aims to investigate the relationships between evolution education, the nature of science, and religious beliefs in U.S. universities by reviewing published research. Specifically, we aim to identify the relationships between the following constructs in U.S. undergraduate students: understanding of ET, acceptance of ET, instruction in ET, prior exposure to ET, religious beliefs, understanding the nature of science, and understanding scientific theories.

\section{Methods}

A review of the literature was conducted to ascertain published studies of evolution education in U.S. universities. We looked for studies that described at least two of the following seven constructs: understanding of ET, acceptance of ET, instruction in ET, prior exposure to ET, religious beliefs, understanding the nature of science, and understanding scientific theories. The following databases supported by EBSCO, an educational database vendor, were searched for articles published from 1980 to 2010: Academic Search Complete, ERIC, Masterfile Premier, Education Research Complete, Professional Development Collection, Psychology and Behavior Science Collection, PsychINFO, Topic Search, and Science and Technology Collection. We also conducted searches through Wilson Web, Web of Knowledge, and Google Scholar. The following key terms were searched in varying order and assortment within each database vendor: evolution, education, teaching, university, attitude, knowledge, understanding, acceptance, religion, undergraduate, assessment, and evaluation. In addition to database vendors, we searched the literature cited by each article included in the review. Using these methods, we feel confident that our review exhausted the available published literature on evolution education in U.S. universities over the last 30 years.

In order to conduct a comparative review, it is necessary to standardize the constructs used across all studies. Researchers tend to vary in the way they label each specific construct even though they often are similarly defined within the publications. Although some might argue that these constructs do not fully encompass their definitions, as defined for this review, the constructs include the major aspects addressed in the studies and provide a common metric to evaluate them. For example, we use the term 
understanding of ET (Scharmann 1990; Sinclair et al. 1997; Sinatra et al. 2003) to cover constructs such as knowledge (Brem et al. 2003; Rice et al. 2011; Wilson 2005) and conception (Bishop and Anderson 1990; Demastes et al. 1995). Acceptance of ET (Sinatra et al. 2003; Sinclair et al. 1997; Wilson 2005) was used to include belief (Bishop and Anderson 1990; Brem et al. 2003; Demastes et al. 1995) and attitude toward evolution (Rice et al. 2011; Scharmann 1990). We also used religious belief as a construct that includes theistic position (Rice et al. 2011) and religious orientation (Wilson 2005).

\section{Results and Discussion}

Through an exhaustive literature search we identified 26 articles that discussed evolution education at the university level over the last 30 years. Five of those studies were conducted internationally (Dagher and BouJaoude 1997 and 2005; Hokayem and BouJaoude 2008; Gregory and Ellis 2009; Pecker et al. 2010), four described teaching strategies for evolution in higher education (Scharmann 1993; Cherif et al. 2001; Alters and Nelson 2002; Kliman and Johnson 2005), and two studies analyzed less than two of the constructs studied here (Winslow et al. 2011; Lord and Marino 1993); therefore, only 15 publications met the criteria to be included in this review. Comparisons between studies are represented in Tables 1, 2, 3, 4 and 5, with Table 1 describing study design, Table 2 detailing participant demographics, Table 3 comparing the relationships between constructs, Table 4 suggesting pedagogical strategies for instruction, and Table 5 listing each publication according to the authors and their university affiliates.

We did not include international universities in the review because national educational systems are inherently different; therefore undergraduate students would not be comparable. Some would argue that undergraduate students from different states would not be comparable since each state is responsible for determining their individual K-12 education standards. We argue, however, that undergraduate students throughout the U.S. are comparable because state education standards are based on national standards and are safeguarded by national organizations (Berkman et al. 2008).

Based on the 15 studies reviewed, we focus primarily on five trends: understanding and instruction of ET, instruction and acceptance of ET, acceptance and understanding of ET, understanding the nature of science and acceptance of ET, and acceptance of ET and religious beliefs. In the following comparisons, we only include studies that conducted some type of statistical analysis to determine a relationship between constructs. Studies without statistical analysis were not included because we cannot make any valid conclusions regarding the relationship between the constructs studied.
There Is a Positive Relationship Between Instruction and Understanding of ET Three out of five studies $(60 \%)$ found that instruction in ET significantly increased students' understanding of ET (Table 3: Scharmann 1990; Demastes et al. 1995; Jensen and Finley 1995; Sinclair et al. 1997; Rice et al. 2011). As educators we like to believe that levels of evolution understanding are mediated by instruction; our results are consistent with this assumption, although only slightly. Interestingly, the two studies that showed no relationship between instruction and understanding used an experimental design (compared two classes, one using an experimental teaching method and the other using a traditional teaching method) while the three studies that showed a statistical relationship used a pre-/post-design with a single group of students (Tables 1 and 2). In order to make this association clear, more experimental designs must be conducted. Similarly, two out of three studies $(66 \%)$ found that prior exposure to evolution, either through secondary or higher education, played a significant role in increasing understanding levels of students (Table 3: Bishop and Anderson 1990; Demastes et al. 1995; Brem et al. 2003).

There Is a Positive Relationship Between Instruction and Acceptance of ET Two out of three studies (66\%) found a statistically positive relationship between evolution instruction and an increased rate of acceptance (Table 3: Matthews 2001; Ingram and Nelson 2006; Rice et al. 2011). All three studies used similar pre-/post-designs in established courses of general biology or evolution. This evidence is consistent with understanding of ET in that instruction will likely increase students' understanding as well as their acceptance levels during the time in which the course is taught. Lombrozo et al. (2008) found that prior exposure was not significantly related to acceptance of evolution, suggesting that instruction only affects short-term acceptance of ET (Table 3). This highlights an interesting relationship regarding short- and long-term understanding and acceptance of evolution. According to Brem et al. (2003), understanding of ET is long term, meaning that past educational experiences affect students' current understanding of ET. Acceptance of ET, however, may not be as strongly influenced in the long term (Lombrozo et al. 2008). These studies suggest that students' acceptance levels can change during the course of a semester (Matthews 2001; Ingram and Nelson 2006; Rice et al. 2011) but that they might revert to previous belief systems over longer periods of time (Lombrozo et al. 2008). Only four studies have looked at this relationship and given their lack of overall consistent results, additional studies that experimentally examine the link between instruction and acceptance of ET, and how this relationship is modulated by time since instruction, are needed to make any conclusive remarks. 





Table 2 Comparison of study demographics for publications investigating evolution education in undergraduate students in U.S. institutions

\begin{tabular}{|c|c|c|c|c|c|c|c|}
\hline Publication & Number & Groups & $\begin{array}{l}\text { Age (range/ } \\
\text { mean) }\end{array}$ & $\begin{array}{l}\text { Gender } \\
\text { (male/female) }\end{array}$ & $\begin{array}{l}\text { Major (most } \\
\text { prominent) }\end{array}$ & $\begin{array}{l}\text { Race (most } \\
\text { prominent) }\end{array}$ & Course type \\
\hline Johnson and Peeples (1987) & 1,812 & None & ND & ND & All-54\% biology & ND & Biology \\
\hline $\begin{array}{l}\text { Bishop and Anderson } \\
\text { (1990) }\end{array}$ & 90 & $\begin{array}{l}\text { Pre (110) } \\
\text { Post (90) }\end{array}$ & ND & ND & All & ND & Nonmajor biology \\
\hline Scharmann (1990) & 30 & $\begin{array}{l}\text { Experimental (13) } \\
\text { Control (17) }\end{array}$ & ND & ND & ND & ND & Nonmajor biology \\
\hline Demastes et al. (1995) & 192 & $\begin{array}{l}\text { Experimental (83) } \\
\text { Control (109) }\end{array}$ & ND & ND & ND & ND & Nonmajor biology \\
\hline Jensen and Finley (1995) & 42 & $\begin{array}{l}\text { Pre (85) } \\
\text { Post (42) }\end{array}$ & ND & ND & ND & ND & Biology \\
\hline Sinclair et al. (1997) & 218 & Pre/post & ND & $31 / 69 \%$ & $57.5 \%$ science related & 91\% White & Introductory zoology \\
\hline Matthews (2001) & 34 & $\begin{array}{l}\text { Pre (37), Post (34), } \\
\text { Post-Post (34) }\end{array}$ & ND & $19 / 81 \%$ & All- $78 \%$ nonscience & $\begin{array}{l}60 \% \\
\text { Caucasian }\end{array}$ & General biology \\
\hline Mckeachie et al. (2002) & 28 & $\begin{array}{l}\text { Pre }(60) \\
\text { Post }(28)\end{array}$ & ND & ND & ND & ND & Introductory biology \\
\hline Brem et al. (2003) & 135 & None & $18-38 / 21.7$ & $51 / 49 \%$ & All-24\% humanities & $\begin{array}{l}40 \% \text { Asian } \\
\text { American }\end{array}$ & None \\
\hline Sinatra et al. (2003) & 93 & None & $18-41 / 20$ & $33 / 63 \%$ & All- $31 \%$ business & $84 \%$ White & Nonmajor biology \\
\hline Wilson (2005) & ND & None & ND & ND & All & ND & $\begin{array}{l}\text { Evolution for all } \\
\text { majors }\end{array}$ \\
\hline Ingram and Nelson (2006) & 225 & None & ND & ND & Mostly biology/health & ND & Upper-level evolution \\
\hline Robbins and Roy (2007) & 141 & None & ND & ND & All & ND & Nonmajor biology lab \\
\hline Lombrozo et al. (2008) & 96 & None & ND & $33 / 67 \%$ & All & ND & None \\
\hline Rice et al. (2011) & 265 & $\begin{array}{l}\text { Pre-Fr. }(82) \\
\text { Post-Fr. (122) } \\
\text { Sr. (61) }\end{array}$ & ND & ND & $\begin{array}{l}\text { Freshman and senior } \\
\text { biology or genetics }\end{array}$ & ND & $\begin{array}{l}\text { Fr.-intro biology } \\
\text { and Sr.- no course }\end{array}$ \\
\hline
\end{tabular}

$N D$ no data (The researchers did not report this information in the publication. They may or may not have collected it), Fr. freshman, $S r$. seniors

There Is No Relationship Between Acceptance And Understanding of ET Four out of five studies (80\%) indicated that there was no statistical association between students' acceptance and understanding of ET (Table 3: Bishop and Anderson 1990; Demastes et al. 1995; Sinatra et al. 2003; Ingram and Nelson 2006; Rice et al. 2011). These comparisons involved a variety of different research designs including pre/post, experimental, and cross-sectional. These results suggest that students do not have to accept evolution as a valid scientific theory in order to understand the theory itself. Conversely, it also suggests that understanding evolution will not necessarily influence acceptance of ET. Even though understanding and acceptance may not be related, they are both influenced by instruction. Therefore, the best way to influence students' understanding and acceptance of ET is to provide them with positive educational experiences (described in Table 4).

There Is a Positive Relationship Between Understanding the Nature of Science and Acceptance of ET Only two of the 15 studies examined the relationship between a students' understanding of the nature of science and their acceptance of ET. Both studies indicate a positive relationship, suggesting that students are more likely to accept evolution as a valid scientific theory if they first understand the nature of science (Table 3: Johnson and Peeples 1987; Lombrozo et al. 2008). This concept is well recognized by professionals who teach evolution in both secondary and higher education (Table 4: Scharmann 1990, 1993; Sinclair et al. 1997; Cherif et al. 2001; Sinatra et al. 2003; Kliman and Johnson 2005; Lombrozo et al. 2008; Rice et al. 2011). Lombrozo et al. (2008) also indicate that students will better understand the nature of science if they have been exposed to it in the past. This is especially important for primary, secondary, and introductory level undergraduate science courses. Laying a solid foundation of what science is, the scientific process, and what it can tell us, is essential for students to understand and appreciate scientific theories, such as evolution.

The Relationship Between Acceptance Of ET and Religious Belief Is Unclear Three studies attempted to study religious beliefs in regard to evolution but utilized very different items to measure these constructs (Brem et al. 2003; Lombrozo et al. 2008; Rice et al. 2011). The results from these studies provide little evidence to either support or deny a relationship between students' religious beliefs and acceptance of evolution. Although these studies quantitatively assessed the relationship between the acceptance of ET 
Table 3 Relationship between the constructs (listed below) used in studies investigating evolution education in undergraduate students in U.S. institutions

\begin{tabular}{|c|c|c|c|c|c|c|c|c|c|}
\hline $\begin{array}{l}\text { Publication } \\
\text { and date }\end{array}$ & $\mathrm{U}$ and $\mathrm{A}$ & $\mathrm{RB}$ and $\mathrm{A}$ & $\mathrm{I}$ and $\mathrm{A}$ & $\mathrm{PE}$ and $\mathrm{A}$ & $\mathrm{RB}$ and $\mathrm{U}$ & $\mathrm{I}$ and $\mathrm{U}$ & $\mathrm{PE}$ and $\mathrm{U}$ & NS and A & PE and NS \\
\hline $\begin{array}{l}\text { Johnson and } \\
\text { Peeples (1987) }\end{array}$ & & & & & & & & $\begin{array}{l}\text { Yes }^{\mathrm{a}} \\
\quad(\uparrow \mathrm{NS}=\uparrow \mathrm{A})\end{array}$ & \\
\hline $\begin{array}{l}\text { Bishop and } \\
\text { Anderson (1990) }\end{array}$ & $\mathrm{No}^{\mathrm{a}}$ & & No & & & & $\mathrm{No}^{\mathrm{a}}$ & & \\
\hline Scharmann (1990) & & & & & & $\mathrm{No}^{\mathrm{a}}$ & & & \\
\hline $\begin{array}{l}\text { Demastes et al. } \\
\text { (1995) }\end{array}$ & $\mathrm{No}^{\mathrm{a}}$ & & No & & & $\mathrm{No}^{\mathrm{a}}$ & $\mathrm{No}^{\mathrm{a}}$ & & \\
\hline $\begin{array}{l}\text { Jensen and Finley } \\
\text { (1995) }\end{array}$ & & & & & & $\mathrm{Yes}^{\mathrm{a}}(\mathrm{I}=\uparrow \mathrm{U})$ & & & \\
\hline $\begin{array}{l}\text { Sinclair et al. } \\
\text { (1997) }\end{array}$ & & & & & & $\mathrm{Yes}^{\mathrm{a}}(\mathrm{I}=\uparrow \mathrm{U})$ & & & \\
\hline Matthews (2001) & & & $\operatorname{Yes}^{\mathrm{a}}(\mathrm{I}=\uparrow \mathrm{A})$ & & & & & & \\
\hline $\begin{array}{l}\text { Mckeachie et al. } \\
(2002)\end{array}$ & & & Yes $(I=\uparrow A)$ & & $\begin{array}{l}\text { Yes } \\
\quad(R B=\downarrow U)\end{array}$ & & & & \\
\hline Brem et al. (2003) & No & & & $\begin{array}{l}\text { Yes } \\
\quad(\uparrow P E=\uparrow A)\end{array}$ & & & $\begin{array}{l}\mathrm{Yes}^{\mathrm{a}} \\
(\mathrm{PE}=\uparrow \mathrm{U})\end{array}$ & & \\
\hline $\begin{array}{l}\text { Sinatra et al. } \\
(2003)\end{array}$ & $\mathrm{No}^{\mathrm{a}}$ & & & & & & & & \\
\hline Wilson (2005) & & & & & & Yes $(I=\uparrow U)$ & & & \\
\hline $\begin{array}{l}\text { Ingram and } \\
\text { Nelson (2006) }\end{array}$ & $\mathrm{No}^{\mathrm{a}}$ & & $\operatorname{Yes}^{\mathrm{a}}(\mathrm{I}=\uparrow \mathrm{A})$ & & & & & & \\
\hline $\begin{array}{l}\text { Robbins and Roy } \\
\text { (2007) }\end{array}$ & & & Yes $(I=\uparrow A)$ & & & & & & \\
\hline $\begin{array}{l}\text { Lombrozo et (al. } \\
\text { 2008) }\end{array}$ & & $\begin{array}{l}\mathrm{Yes}^{\mathrm{a}} \\
\quad(\mathrm{RB}=\downarrow \mathrm{A})\end{array}$ & & $\mathrm{No}^{\mathrm{a}}$ & & & & $\begin{array}{l}\mathrm{Yes}^{\mathrm{a}} \\
\quad(\uparrow \mathrm{NS}=\uparrow \mathrm{A})\end{array}$ & $\begin{array}{l}\mathrm{Yes}^{\mathrm{a}} \\
\quad(\uparrow \mathrm{PE}=\uparrow \mathrm{NS})\end{array}$ \\
\hline Rice et al. (2011) & $\begin{array}{l}\text { Yes }^{\mathrm{a}} \\
(\uparrow \mathrm{U}=\uparrow \mathrm{A})\end{array}$ & & $\mathrm{No}^{\mathrm{a}}$ & & & $\operatorname{Yes}^{\mathrm{a}}(\mathrm{I}=\uparrow \mathrm{U})$ & & & \\
\hline
\end{tabular}

"Yes" indicates that the researchers identified a relationship between two constructs. "No" indicates that they did not identify a relationship. Arrows indicate if the construct increased or decreased due to its relationship with another construct. Constructs measured: acceptance of evolutionary theory (A), understanding of evolutionary theory (U), instruction in evolutionary theory (I), prior exposure to evolutionary theory (PE), religious beliefs (RB), and understanding the nature of science (NS)

${ }^{\mathrm{a}}$ Results were analyzed statistically

and religious beliefs, they suffer from substantial but different limitations. Below, we discuss the studies, recognizing the drawbacks in their methodology that preclude clear interpretations of their findings with the hopes of better guiding future research.

Brem et al. (2003) and Rice et al. (2011) adopted two different approaches for identifying participants' religious beliefs and views on evolution, but both studies used a single-answer item measured along a continuum between evolution and religion. As it is a single item, it can only measure a single construct; therefore, it cannot be used to make any comparisons between religious beliefs and evolution. A single construct like this only explains where a person's belief exists on a continuum between religious beliefs and evolution, blurring the relationship between the two. Although using a single construct to assess this continuum may be appropriate for some studies, if a researcher is trying to determine the relationship between the two constructs, using a single item is inherently invalid, given that no comparison can be made. Given this limitation, the findings reported in these two studies need to be considered with caution. Brem et al. (2003) reported that acceptance of ET was positively related to an increase in understanding and prior exposure, but their measure of acceptance was based on the continuum between students' religious beliefs and views on evolution. Rice et al. (2011) also used this continuous one-item construct to determine that increasing students' understanding of ET will also increase their acceptance of ET. In order to statistically determine validity of survey items and constructs, there must be at least three items per construct (Gorsuch 1997); these studies, however, just used one item to determine acceptance of ET. Lombrozo et al. (2008) used an approach for determining acceptance and religious beliefs using multiple, separate items.

Lombrozo et al. (2008) assessed religious beliefs by using a series of items based on a list of statements. The relationship between the constructs in this study, however, is based on individual items and does not represent any kind of continuum between religion and science. This could be a drawback of this study considering that not all people may 
Table 4 Suggestions for increasing student understanding of evolution based on the fifteen studies included in this review, along with four additional studies that described teaching strategies in higher education, and Craig Nelson's essay (2000)

\begin{tabular}{|c|c|}
\hline Suggestions & Publication \\
\hline Clearly define and discuss the nature of science & $\begin{array}{l}\text { Scharmann (1990, 1993), Sinclair et al. (1997), Nelson (2000), Cherif et al. (2001), } \\
\text { Alters and Nelson (2002), Sinatra et al. (2003), Kliman and Johnson (2005), } \\
\text { Lombrozo et al. (2008), and Rice et al. (2011) }\end{array}$ \\
\hline Clearly define and discuss scientific theories & $\begin{array}{l}\text { Scharmann (1993), Sinclair et al. (1997), Nelson (2000), Alters and Nelson (2002), } \\
\text { Wilson (2005), Kliman and Johnson (2005), and Lombrozo et al. (2008) }\end{array}$ \\
\hline Develop critical thinking skills & $\begin{array}{l}\text { Nelson (2000), Alters and Nelson (2002), Ingram and Nelson (2006), and } \\
\text { Lombrozo et al. (2008) }\end{array}$ \\
\hline $\begin{array}{l}\text { Use a diversified instructional strategy based on active } \\
\text { learning techniques }\end{array}$ & $\begin{array}{l}\text { Scharmann (1990, 1993), Jensen and Finley (1995), Sinclair et al. (1997), Nelson } \\
\text { (2000), Cherif et al. (2001), Alters and Nelson (2002), McKeachie et al. (2002), } \\
\text { Sinatra et al. (2003), and Wilson (2005) }\end{array}$ \\
\hline $\begin{array}{l}\text { Discuss religious beliefs along with evolution but do not be } \\
\text { adversarial concerning student's religious beliefs }\end{array}$ & $\begin{array}{l}\text { Johnson and Peeples (1987), Sinclair et al. (1997), Matthews (2001), Sinatra et al. } \\
\text { (2003), Ingram and Nelson (2006), and Robbins and Roy (2007) }\end{array}$ \\
\hline $\begin{array}{l}\text { Discuss the students' tendency to make a dichotomous choice } \\
\text { between evolution and religious beliefs }\end{array}$ & $\begin{array}{l}\text { Scharmann (1990), Sinclair et al. (1997), Nelson (2000), and Alters and Nelson } \\
\text { (2002) }\end{array}$ \\
\hline $\begin{array}{l}\text { Utilize a conceptual-change learning model (a constructivist } \\
\text { approach) }\end{array}$ & $\begin{array}{l}\text { Bishop and Anderson (1990), Scharmann (1993), Demastes et al. (1995), Jensen } \\
\text { and Finley (1995), Matthews (2001), and Alters and Nelson (2002) }\end{array}$ \\
\hline $\begin{array}{l}\text { Discuss multiple perspectives associated with evolution and } \\
\text { their implications on society }\end{array}$ & Brem et al. (2003) and Wilson (2005) \\
\hline $\begin{array}{l}\text { Use the theory of evolution as a central theme for developing } \\
\text { course content in introductory biology courses }\end{array}$ & Sinclair et al. (1997) \\
\hline Discuss human evolution & Nelson (2000) and Wilson (2005) \\
\hline $\begin{array}{l}\text { Explain to students that evolution is important in their } \\
\text { everyday lives }\end{array}$ & Kliman and Johnson (2005) \\
\hline
\end{tabular}

view science and religion as mutually exclusive domains. Winslow et al. (2011), for instance, suggest that most peoples' beliefs exist on a continuum and that very few people are strictly creationists or evolutionists. Having two items, however, allows for a direct comparison between the two constructs of religious belief and acceptance of ET. Lombrozo et al. (2008) found that students with strong religious beliefs were less likely to accept ET than those without wellestablished religious beliefs (Table 3). Two items from the religiosity scale accounted for the majority of this negative correlation - belief in God and in an afterlife. Surprisingly, the item concerning perceived conflict between science and religion was not significantly correlated with students' responses on the evolution acceptance items.

When considering assessing religious beliefs, it is crucial to consider the nature of religion and specifically whether the items allow for religions with single as well as multiple divine entities. The construct used by Brem et al. (2003), for instance, does not assume a specific monotheistic religion, and participants were allowed to express their beliefs on a continuum. The authors also allowed participants to further express their beliefs if they thought it was necessary, using an open-ended item. For the sample in this study, a single item was sufficient for $58 \%$ of the participants to express their views on religion and evolution. Thirty-four percent of the participants felt that it was an adequate scale if they were allowed to choose more than one statement. Therefore, more than $90 \%$ felt that they were able to express their views using the quantitative scale without having to supplement with qualitative information. Rice et al. (2011) used an item that presented a continuum of beliefs but represented only a limited amount of religions (Judaism, Christianity, and Islam) by including the creation story found in Genesis. Considering that the study was conducted at a public university and not a private religious-based university, it is likely that this particular item was not relevant to all religions practiced by the students. Lombrozo et al. (2008) used a scale that presented religion ambiguously in that no particular religious God was identified. It did, however, assume a monotheistic God. Instruments that allow for diverse religious beliefs are necessary to examine its relationship with science. Such instruments are crucial for studies investigating higher education in the U.S., considering the increase in religious diversity in this country over the last decades (Wuthnow 2007).

Finally, one of the most prominent issues with the constructs used by the studies described above is that no information is given concerning the validity of the items; therefore, it is unclear if the authors measured what they were designed to measure - the continuum between religious beliefs and acceptance of evolution. Brem et al. (2003) and Rice et al. (2011) claimed to pilot-test their instruments but no data were given to validate that statement. Lombrozo et al. (2008) do not mention piloting their 
Table 5 Date, journal, author, and university affiliate of each publication used in the review

\begin{tabular}{|c|c|c|c|}
\hline Year & Author & Author's department or college and university (at time of publication) & Journal \\
\hline 1987 & $\begin{array}{l}\text { Johnson, R.L. } \\
\text { Peeples, E.E. }\end{array}$ & $\begin{array}{l}\text { Biology, Springfield College } \\
\text { Biology, University of Northern Colorado }\end{array}$ & The American Biology Teacher \\
\hline 1990 & $\begin{array}{l}\text { Bishop, B.A. } \\
\text { Anderson, C.W. }\end{array}$ & $\begin{array}{l}\text { College of Education, Michigan State University } \\
\text { College of Education, Michigan State University }\end{array}$ & Journal of Research in Science Teaching \\
\hline 1990 & Scharmann, L.C. & Center for Science Education, Kansas State University & School Science and Mathematics \\
\hline 1995 & $\begin{array}{l}\text { Demastes, S.S } \\
\text { Settlage, J. Jr. } \\
\text { Good, R. }\end{array}$ & $\begin{array}{l}\text { Educational Studies, University of Utah } \\
\text { College of Education, Cleveland State University } \\
\text { Curriculum and Instruction, Louisiana State University }\end{array}$ & Journal of Research in Science Teaching \\
\hline 1995 & $\begin{array}{l}\text { Jensen, M.S. } \\
\text { Finley, F.N. }\end{array}$ & $\begin{array}{l}\text { General College, University of Minnesota } \\
\text { College of Education, University of Minnesota }\end{array}$ & Science Education \\
\hline 1997 & $\begin{array}{l}\text { Sinclair, A. } \\
\text { Pendarvis, M.P. } \\
\text { Baldwin, B. }\end{array}$ & $\begin{array}{l}\text { NA, Southeastern Louisiana University } \\
\text { NA, Southeastern Louisiana University } \\
\text { NA, Southeastern Louisiana University }\end{array}$ & $\begin{array}{l}\text { Journal of Research and Development in } \\
\text { Education }\end{array}$ \\
\hline 2001 & Matthews, D. & The Sage Colleges in Albany and Troy & The American Biology Teacher \\
\hline 2002 & $\begin{array}{l}\text { McKeachie, W.J. } \\
\text { Lin, Y.G. }\end{array}$ & $\begin{array}{l}\text { Psychology, University of Michigan } \\
\text { Center for Research on Learning and Teaching, University of } \\
\text { Michigan }\end{array}$ & The American Biology Teacher \\
\hline & Strayer, J. & Biology, Washtenaw Community College & \\
\hline 2003 & $\begin{array}{l}\text { Sinatra, G.M. } \\
\text { Southerland, } \\
\text { S.A. } \\
\text { McConaughy, F. } \\
\text { Demastes, J.W. }\end{array}$ & $\begin{array}{l}\text { Educational Psychology, University of Nevada } \\
\text { Middle and Secondary Education, Florida State University } \\
\text { NA, Weber State University } \\
\text { Biology, University of Northern Iowa }\end{array}$ & Journal of Research in Science Teaching \\
\hline 2003 & $\begin{array}{l}\text { Brem, S.K. } \\
\text { Ranney, M. } \\
\text { Schindel, J. }\end{array}$ & $\begin{array}{l}\text { Psychology in Education, Arizona State University } \\
\text { Cognition and Development, University of California, Berkley } \\
\text { Psychological Studies in Education, Stanford University }\end{array}$ & Science Education \\
\hline 2005 & Wilson, D.S. & Biology and Anthropology, Binghamton University & PLoS Biology \\
\hline 2006 & $\begin{array}{l}\text { Ingram, E.L. } \\
\text { Nelson, C.E. }\end{array}$ & $\begin{array}{l}\text { Applied Biology and Biomedical Engineering, Rose-Hulman Institute } \\
\text { of Technology } \\
\text { Biology, Indiana University }\end{array}$ & Journal of Research in Science Teaching \\
\hline 2007 & $\begin{array}{l}\text { Robbins, J.R. } \\
\text { Roy, P. }\end{array}$ & $\begin{array}{l}\text { Biology, Xavier University } \\
\text { Biology, Xavier University }\end{array}$ & The American Biology Teacher \\
\hline 2008 & $\begin{array}{l}\text { Lombrozo, }^{\text {a }}{ }^{\text {a }} \\
\text { Thanukos, A. } \\
\text { Weisberg, M. }\end{array}$ & $\begin{array}{l}\text { Psychology, University of California, Berkley } \\
\text { Museum of Paleontology, University of California, Berkley } \\
\text { Philosophy, University of Pennsylvania }\end{array}$ & Evolution Education Outreach \\
\hline 2010 & Rice, J.W. & $\begin{array}{l}\text { Ecology, Evolution, and Organismal Biology, Iowa State University } \\
\text { Curriculum and Instruction, Iowa State University }\end{array}$ & Evolution Education Outreach \\
\hline
\end{tabular}

$N A$ not applicable (the department was not indicated in the publication)

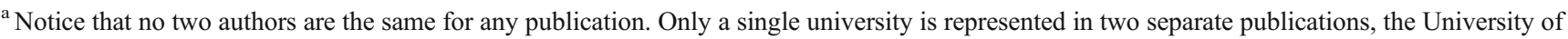
California, Berkley; however, the authors are from different departments and the publications are five years apart

instrument. Even though some of the instruments they used are based on previous instruments, the authors also claim to have created some new items. All three publications failed to distinguish between new and old items; therefore, it is impossible to know whether the items measuring religious belief are valid or reliable. Any future studies using these items should be tested, and the investigators should also report how such items perform statistically. Overall, researchers interested in directly examining the effect of religious beliefs on the acceptance of ET must be especially careful to design instruments that accurately and precisely assess the constructs they intend to measure. We strongly recommend careful attention to the following three aspects: avoiding using a single construct, using instead a series of items that represent a continuum between religious beliefs and science; use of instruments that do not assume monotheism or specific religious views; and testing and reporting the validity of the instruments used in the study. 
Apparent Problems for Evolution Education in Universities

Although some trends were recognized in the published studies, there is still much to be learned in this area. The primary problems associated with this field of research are: small sample size, varying methodologies, lack of statistical analysis, inappropriate use of constructs, and lack of continuity among studies. In our literature review, we found 26 studies that relate to evolution in higher education; only 15 of those, however, directly assessed at least two of the most commonly studied constructs in evolution education. The low number of constructs shared among studies, combined with the few studies published in this field, increases the challenge of recognizing overall trends within and among constructs. In addition, there is a lack of standardized methodology for evaluation among the few studies published. This methodology need not be a strict protocol of constructs and evaluative instruments, but the field desperately needs a general framework on which to base all future studies. Without a general framework, research in this field will persist with sporadic, haphazard side projects that will continue to disjoin the field of university-level evolution education instead of building on established knowledge.

Another concern regarding studies published in this field over the last 30 years is the lack of use of statistical tools to evaluate the relationships among variables. Researchers often drew strong conclusions from data that may not be statistically supported. Some studies were strictly quantitative while others used a mixed methods approach (none of the studies compared used a strictly qualitative methodology), so each publication should be reporting statistical analyses and making conclusions strictly on those results that are statistically supported. Hand-waving speculation is susceptible to being affected by preliminary biases and thus does nothing to advance this important and developing field.

Careful attention should be paid to each intended construct and the items used to measure that construct. For example, researchers should be careful to avoid using items that only assess specific religious beliefs in populations where multiple religions are likely to occur. Also, it is unlikely that most people view religion and science as mutually exclusive domains, so an ordinal or continuous scale should be used to measure this interface. Lastly, researchers should be attentive to the number of items used to measure the relationship between religious beliefs and acceptance of ET. Comparisons between these constructs cannot be made if a single item is used. In order to avoid such problems, it would be highly beneficial for evolution educators to collaborate with experts in survey development and design. Often the researchers developing projects in this field are experts in evolution, but they lack the skills to develop an instrument that is both reliable and valid when measuring evolution constructs. Given the strong interdisciplinary aspect of projects like these, which bridge between evolution and education, collaborations among experts from both fields are necessary to develop robust methodologies.

Finally, there is no expert in the field of universitylevel evolution education. Based on the 15 publications cited, not a single study shared authors (Table 5), suggesting that these studies were probably side projects or graduate student projects. Once a paper was published, the authors did not follow up their study to further examine the complexity of the relationships detected. Both C Nelson and B Alters have multiple publications discussing this field, however, both researchers lack a sufficient number of empirical publications on the issue (Nelson 2000, Alters and Alters 2001, Alters and Nelson 2002, Ingram and Nelson 2006). Moreover, there is a vast array of departments represented in the publications, ranging from the obvious biology and education departments to the Museum of Paleontology. Even the universities represented in the publications were different. Only a single university was represented more than once among the authors, University of California at Berkley. These studies, however, were published five years apart and the authors were from different departments, suggesting that these projects do not represent a natural continuation of a growing idea. In summation, there is a strong lack of consistency among those researchers who have published on university-level evolution education.

According to this analysis, evolution education is associated with an increase in understanding and acceptance of ET. Even though these results indicate that evolution education works, the limitations identified in the 15 publications reviewed emphasizes the need for more empirical evidence. If scientists want to persuade policy makers and curriculum designers to include an evolution course for all undergraduate students, then the field needs a stronger research foundation.

\section{Strategies for Teaching Evolution in Higher Education}

Although the lack of consistency in authorship presents apparent problems with methodology and connectedness of research, it does provide us with a diverse set of suggestions on how to make evolution education in universities more productive. Table 4 provides suggestions for education presented in the 15 publications studied, four studies that described teaching strategies in higher education, and Craig Nelson's essay titled "Effective Strategies for Teaching Evolution and other Controversial Topics" (2000). Below, we elaborate on these suggestions with specific examples (see Table 4 for references).

First and foremost, it is important for instructors to establish a good understanding of the nature of science and of 
scientific theories. Without this knowledge, students will not be able to objectively assess the theory of evolution. In addition, students must learn to think critically about science. This can be done by emphasizing the role of discovery, innovation, and creativity in scientific hypotheses and methodologies. Similarly, it would be beneficial to demonstrate how scientists use experiments to test ET to facilitate linking student understanding of the scientific process with ET itself.

Current educational research shows the importance of using various instructional methods and incorporating a number of active learning strategies in order to increase the probability of learning among their students (Armbruster et al. 2009; Freeman et al. 2007; Wood 2009). Here we include a list of general teaching strategies suggested by the researchers cited in Table 4: design experiments that require students to make their own conclusions based on scientific evidence; allocate a specific amount of time to discuss students' misconceptions; and conduct small group discussions to induce and reinforce student learning (Scharmann 1990, 1993; Jensen and Finley 1995; Sinclair et al. 1997; Cherif et al. 2001; McKeachie et al. 2002; Sinatra et al. 2003; Wilson 2005). In addition to general strategies, these researchers included some techniques that are specific to evolution education: organize field trips to observe differences in flora and fauna first hand; use multimedia in classrooms so that students can visualize the earth's biodiversity; mediate interactive discussion sessions regarding the potential controversies between evolution and creationism; have students write personal evaluations concerning evolution and justify their reasoning; have students choose a topic (e.g., morning sickness during pregnancy or the antimicrobial properties of spices) to explore from an evolutionary perspective; utilize readings in natural history to study evolutionary principles; use geological concepts to teach evolution; and have students debate evolution, creationism, and the compatibility of both (Scharmann 1990, 1993; Jensen and Finley 1995; Sinclair et al. 1997; Cherif et al. 2001; McKeachie et al. 2002; Sinatra et al. 2003; Wilson 2005). Based on our experience, successful strategies also include active learning exercises that create excitement in the classroom and guide students to solve by themselves mysteries for which the answer is found only once considered in the light of evolution. Such activities promote self-discovery and ignite the curiosity of students to learn about ET. Given that over $60 \%$ of the students in our evolution class intend to pursue health-related professions, activities related to Darwinian medicine or forensic science are particularly effective.

The level of compatibility between science and religion is a major concern for many students and should be addressed by professors. Researchers emphasize the importance of discussing religious beliefs along with ET while not being adversarial concerning student's religious beliefs (Johnson and Peeples 1987; Sinclair et al. 1997; Matthews 2001; Sinatra et al. 2003; Ingram and Nelson 2006; Robbins and Roy 2007). These authors suggested that the goal of an educator should not be to persuade students to accept evolution but to explain what science can and cannot explainto take their beliefs seriously while also emphasizing that all claims will be scrutinized scientifically. This will help students discriminate between real science and nonscience. Also, it is important to discuss students' tendency to make a dichotomous choice between evolution and their religious beliefs. The two do not have to be mutually exclusive, even though many fundamentalists believe them to be.

Three of the 15 studies reviewed described using a conceptual change (constructivist) approach to evolution education (Jensen and Finley 1995; Demastes et al. 1995, and Bishop and Anderson 1990). This model allows students to express their initial ideas of evolution, encourages studentstudent and teacher-student interactions, and allows students to reflect on evolutionary concepts through relevant learning experiences. Although this model is recommended by three publications, it is important to note that only Jensen and Finley (1995) found that instruction using conceptual change increased student understanding of evolution over the course of the semester. Demastes et al. (1995) and Bishop and Anderson (1990) showed that conceptualchange instruction and understanding were not related. The conceptual-change model of learning is still questionable in evolution education at the university level, and studies comparing the effectiveness of this model to traditional ones in increasing understanding and acceptance of ET are necessary.

In addition to the general strategies listed above, researchers have suggested three course content modifications to improve students' understanding of evolution. First, any instructor teaching a biology course should be using the theory of evolution as a central theme for course content development (Sinclair et al. 1997). Second, it is beneficial to discuss the molecular, paleontological, and behavior evidence supporting human evolution (Nelson 2000; Wilson 2005). Lastly, explain to students that evolution is important in their everyday lives by affecting healthcare, agriculture, the economy, etc. For example, people die in large numbers from pathogens, and insects develop resistance to pesticides; both of which can affect the nation's economy (Kliman and Johnson 2005). By using these examples, you can help students to connect everyday occurrences to bigger social issues like morality and social equality (Brem et al. 2003; Wilson 2005).

Based on the literature, we found that instruction has a significant and positive effect on acceptance and understanding of ET; acceptance and understanding, however, are not directly related. We also found that the relationship 
between acceptance of ET and religious beliefs is unclear and needs further research. Through reviewing 15 published studies, we found that the primary problems associated with this field of research are: small sample size, varying methodologies, lack of statistical analysis, inappropriate use of constructs, and lack of continuity among studies. We also discussed teaching strategies that researchers claim to be beneficial for undergraduate students. This review exposes the need for a unifying framework and development of experts in this field to investigate and understand the factors that affect evolution education at U.S. universities. After a unified framework is developed, future studies in this field could concentrate on explaining how misconceptions have the potential to impede appropriate understanding of evolution and describing if (and which) religions interfere with the acceptance of evolution and how those beliefs bias student understanding.

\section{Conclusions}

Clearly, there is a strong interest in undergraduate evolution education among many disciplines, but research efforts have been spread over several studies that are not comparable. Unfortunately, this has caused the field to be disjointed, making it hard to identify general trends across research projects. This review is an invitation to establish collaborations between experts in evolution and education to develop a robust and standardized framework so studies build upon each other and allow us to move beyond detecting patterns of association among constructs to investigating the causality of those relationships.

Acknowledgments We would like to express our gratitude to the people who reviewed and provided constructive feedback for this manuscript: Richard E. Strauss, Nova Coker, and Stephanie Lockwood.

\section{References}

Alters BJ, Alters S. Defending science in the classroom. Burlington: Jones \& Bartlett Learning; 2001. p. 111-2.

Alters B, Nelson C. Perspective: teaching evolution in higher education. Evolution. 2002;56(10):1891-901.

American Association for the Advancement of Science. Project 2061: science for all Americans. Washington: AAAS; 1989.

Armbruster P, Matel M, Johnson E, Weiss M. Active learning and student centered pedagogy improve student attitudes and performance in introductory biology. CBE Life Sci Educ. 2009;8 (3):203-13.

Berkman MB, Pacheco JS, Plutzer E. Evolution and creationism in America's classrooms: a National portrait. PLoS Biol. 2008;6 (5):920-4.

Bishop BA, Anderson CW. Student conceptions of natural selection and its role in evolution. J Res Sci Teach. 1990;27:415-27.
Brem SK, Ranney M, Schindel J. Perceived consequences of evolution: college students perceive negative personal and social impact in evolutionary theory. Sci Educ. 2003;87:181-206.

Cherif A, Adams G, Loehr J. What on Earth is evolution: the geological perspective of teaching evolutionary biology effectively. Am Biol Teach. 2001;63(8):569-91.

Colburn A, Henriques L. Clergy views on evolution, creationism, science, and religion. J Res Sci Teach. 2006;43:419-42.

Dagher ZR, BouJaoude S. Scientific views and religious beliefs of college students: the case of biological evolution. J Res Sci Teach. 1997;34(5):429-45.

Dagher ZR, BouJaoude S. Students' perceptions of the nature of evolutionary theory. Sci Educ. 2005;89(3):378-91.

Demastes SS, Settlage J, Good R. Students' conceptions of natural selection and its role in evolution: cases of replication and comparison. J Res Sci Teach. 1995;32(5):535-50.

Dobzhansky T. Nothing in biology makes sense except in the light of evolution. Am Biol Teach. 1973;35:125-129.

Flammer L. The evolution solution: teaching evolution without conflict. Am Biol Teach. 2006;1-7.

Freeman S, Herron JC. Evolutionary analysis, fourth edition. Upper Saddle River: Pearson Education, Inc; 2007.

Freeman S, O'Conner E, Parks JW, Cunningham M, Hurley D, Haak D, Dirks C, Winderoth MP. Prescribed active learning increases performance in introductory biology. CBE Life Sci Educ. 2007;6 (2):132-9.

Gorsuch RL. Exploratory factor analysis: its role in item analysis. J Personal Assess. 1997;68(3):532-60.

Gregory TR, Ellis CA. Conceptions of evolution among science graduate students. BioScience. 2009;59(9):792-9.

Haslam F, Treagust DF. Diagnosing secondary students' misconceptions of photosynthesis and respiration in plants using a two-tier multiple choice instrument. J Biol Educ. 1987;21:203-11.

Hokayem H, BouJaoude S. College students' perceptions of the theory of evolution. J Res Sci Teach. 2008;45(4):395-419.

Ingram EL, Nelson CE. Relationship between achievement and students' acceptance of evolution or creation in an upper-level evolution course. J Res Sci Teach. 2006;43(1):7-24.

Jensen MS, Finley FN. Teaching evolution using historical arguments in a conceptual change strategy. Sci Educ. 1995;79(2): 147-66.

Johnson RL, Peeples EE. The role of scientific understanding in college: student acceptance of evolution. Am Biol Teach. 1987; 49(2):93-8.

Kaufman D, Thanukos A, Ranney M, Brem S, Kwong C. Exploring the relationship between conceptual understanding and evolutionary reasoning. Annual Meeting of the American Educational Research Association. Montreal, Quebec; 1999.

Kliman RM, Johnson NA. What every undergraduate should know about evolution (and why). BioScience. 2005;5(11):926-7.

Laudan L. The demise of the demarcation problem. In: Ruse M, editor. But is it science? Buffalo: Prometheus Books; 1988.

Lawson AE, Wornsop WA. Learning about evolution and rejecting a belief in special creation: effects of reflective reasoning skill, prior knowledge, prior belief, and religious commitment. J Res Sci Teach. 1992;29(2):143-66.

Liang LL, Chen S, Chen X, Kaya ON, Adams AD, Macklin M, et al. Student understanding of science and scientific inquiry: revision and further validation of an assessment instrument. Annual Conference of the National Association of Research in Science Teaching, San Francisco, CA; 2006.

Lombrozo T, Thanukos A, Weisberg M. The importance of understanding the nature of science for accepting evolution. Evol Educ Outreach. 2008;1:290-8.

Lord T, Marino S. How university students view the theory of evolution. J Coll Sci Teach. 1993;22(6):353-7. 
Matthews D. Effect of a curriculum containing creation stories on attitudes about evolution. Am Biol Teach. 2001;63(6):404-9.

McKeachie WJ, Lin Y-G, Strayer J. Creationist vs. evolutionary beliefs: effects on learning biology. Am Biol Teach. 2002;64(3):189-92.

Miller JD, Scott EC, Okamoto S. Public acceptance of evolution. Science. 2006;313:765-6.

Moore R, Kraemer K. The teaching of evolution and creationism in Minnesota. Am Biol Teach. 2005;67:457-66.

National Academy of Sciences. Science and creationism: a view from the National Academy of Sciences. Washington: National Academy Press; 1999.

National Center for Science Education. Evolution education: understanding and teaching the science of evolution. 2012. http://ncse. com/evolution. Accessed 23 January 2012.

National Research Council. Mathematics, Science and Technology Education: a research agenda. Washington: National Academy Press; 1985.

Nelson CE. Effective strategies for teaching evolution and other controversial topics. In: The creation controversy \& the science classroom. Arlington: NSTA Press; 2000.

Pecker D, Comert GG, Kence A. Three decades of anti-evolution campaign and its results: Turkish undergraduates' acceptance and understanding of the biological evolution theory. Sci Educ. 2010;19(6-8):739-55.

Ratzsch D. Humanness in their hearts: where science and religion fuse. In: Schloss J, Murray M, editors. The believing primate: scientific, philosophical and theological reflections on the origin of religion. Oxford: Oxford University Press; 2009. pp. 215-245.

Reiss MJ. The relationship between evolutionary biology and religion. Evolution. 2009;63(7):1934-41.

Rice JW, Olson JK, Colbert JT. University evolution education: the effect of evolution instruction on biology majors' content knowledge, attitude toward evolution, and theistic position. Evol Educ Outreach. 2011;4:137-44.

Robbins JR, Roy P. The natural selection: identifying and correcting non-science student preconceptions through an inquiry-based, critical approach to evolution. Am Biol Teach. 2007;69(8):460-6.

Roy R. Scientism and technology as religions. Zygon. 2005;40(4):835-44.

Rutledge ML, Mitchell MA. High school biology teachers' knowledge structure, acceptance and teaching of evolution. Teach Evol. 2002;64(1):21-7.

Sa W, West RF, Stanovich KE. The domain specificity and generality of belief bias in reasoning and judgment. J Educ Psychol. 1999;91:497-510.

Scharmann LC. Enhancing an understanding of the premises of evolutionary theory: the influence of a diversified instructional strategy. Sch Sci Math. 1990;90(2):91-100.
Scharmann LC. Teaching evolution: designing successful instruction. Am Biol Teach. 1993;55(8):481-6.

Schommer M. Effects of beliefs about the nature of knowledge on comprehension. J Educ Psychol. 1990;82(3):498-504.

Settlage J, Jensen M. Investigating the inconsistencies in college student responses to natural selection test questions. Electron J Sci Educ. 1996;1(1).

Shtulman A, Valcarcel J. Scientific knowledge surpresses but does not supplant earlier intuitions. Cognition. 2012;124:209-15.

Sinatra GM, Southerland SA, McConaughy F, Demastes JW. Intentions and beliefs in students' understanding and acceptance of biological evolution. J Res Sci Teach. 2003;40 (5):510-28.

Sinclair AS, Baldwin B. High school biology students' beliefs about evolutionary theory and religion. Res Schools. 1995;2(2):31-8.

Sinclair A, Pendarvis MP, Baldwin B. The relationship between college zoology students' beliefs about evolutionary theory and religion. J Res Dev Educ. 1997;30(2):118-25.

Smith MU. Counterpoint: belief, understanding, and the teaching of evolution. J Res Sci Teach. 1994;31(5):591-7.

Smith $\mathrm{H}$. Why religion matters: the fate of the human spirit in an age of disbelief. New York: HarperCollins; 2001.

Stanovich KE. Who is rational? Studies of individual differences in reasoning. Mahwah: LEA; 1999.

Trani R. I won't teach evolution; it's against my religion: and now for the rest of the story. Am Biol Teach. 2004;66(6):419-27.

United States Census Bureau. Educational Attainment in the United States: 2003. $2004 \mathrm{http}: / / w w w . c e n s u s . g o v / p r o d / 2004 p u b s / p 20-$ 550.pdf. Accessed 8 January 2012.

Wilson DS. Evolution for everyone: how to increase acceptance of, interest in, and knowledge about evolution. PLoS Biol. 2005;3 (12):2058-65.

Winslow MW, Staver JR, Scharmann LC. Evolution and personal religious belief: Christian university biology-related majors' search for reconciliation. J Res Sci Teach. 2011;48(9):10261049

Wood WB. Innovations in teaching undergraduate biology and why we need them. Annu Rev Cell Dev Biol. 2009. http://www.physics. emory.edu/Faculty/weeks/journal/wood-arcdb09.pdf. Accessed 1 June 2012.

Wuthnow R. Religious Diversity in a "Christian Nation": American Identity and American Democracy. In: Banchoff T, editor. Democracy and the new religious pluralism. New York: Oxford University Press; 2007. p. 151-68.

Zimmerman M. The evolution-creation controversy: opinions of Ohio high school biology teachers. Ohio J Sci. 1987;87(4):115-25. 